\title{
Adult Extraskeletal Osteosarcoma
}

National Cancer Institute

\section{Source}

National Cancer Institute. Adult Extraskeletal Osteosarcoma. NCI Thesaurus. Code C7925.

An osteosarcoma arising from the soft tissue, and occurring in adults. 